\title{
Time and Cost Evaluation of Construction of Steel Framed Composite Floor with Precast Concrete Floor Structure
}

\author{
U. D. Dabhade' ${ }^{1}$ N.A.Hedaoo 2 , Dr. L. M. Gupta ${ }^{3}$ and Dr. G. N. Ronghe ${ }^{4}$ \\ ${ }^{1}$ M.Tech. (C.M) Student, Department of Civil Engineering, College of Engineering, Pune-411005, India; PH \\ 091-020-25507090; FAX 091-020-25507299;e-mail: u_dabhade@yahoo.co.in \\ ${ }^{2}$ Sr.Lecturer, Department of Civil Engineering, Govt. College of Engineering, Pune-411005, India; PH \\ 091-020-25507090 FAX 091-020-25507299; e-mail: nahedaoo@yahoo.com \\ 3,4 Professor, Department of Applied Mechanics, Visvesvaraya National Institute of Technology, Nagpur-11, \\ india; PH 091-0712-2222828; FAX 091-020-2223230; e-mail: lmgupta_vrce@yahoo.co.in and e-mail: \\ gnronghe@indiatimes.com
}

\begin{abstract}
The present scenario in India, particularly in metro cities has restricted the horizontal growth, which led to the vertical growth for building construction. Today, fast track construction is a rapidly growing economy, brings rising costs and therefore time saving in construction can compensate significant proportions of the overall construction cost.

This paper presents a study on, time and cost wise feasibility of steel framed composite floor building. A case study considered for this work is 10 storied multilevel cars parking building. A major feature of this building is post-tensioned composite steel beams having span of $16 \mathrm{~m}$. Considering same plan, floor area, floor to floor height and loading conditions, this existing building is designed and constructed by other two ways viz. precast concrete frame with precast concrete floor and steel frame with precast concrete floor. While designing the above structure with precast concrete frame with precast concrete floor, one additional column is introduced in between $16 \mathrm{~m}$ span lengths to the overall plan to suit the design criterion.

The Microsoft Project-2003 used for time scheduling and the optimum time required at different stages of all these three buildings are calculated. The total cost of each structure is calculated as material and construction costs of each structural element only. The results shows that steel frame with composite deck floor saves $55.3 \%$ construction time than precast frame with precast concrete floor and $14.3 \%$ compared to steel frame with precast concrete floor. However, this required extra $23.10 \%$ of direct cost and $12.99 \%$ of net cost for precast frame with precast concrete floor while $0.52 \%$ and $-2.34 \%$ for steel frame with precast concrete floor.
\end{abstract}

Keywords: Composite floor construction; Post-tensioned composite beam; Precast Concrete floor; Time scheduling; Cost evaluation;

\section{Introduction}

One of the biggest revolutions came with introduction of hot-rolled steel section and cold-formed steel decking as a construction material for high-rise buildings. Steel framed structures with the composite floor would bring considerable economies to the overall cost of the project during its lifetime [10]. The increased popularity of steel framed construction over the last two decades is due to the advantages arising from the use of composite floor. The precast slab panels ideally suited for spans upto $4.2 \mathrm{~m}$, but can be used for large spans by providing secondary beams. For estimation of time and cost of composite floor systems, various authors have been presented the papers $[4,5,6,8]$ in journals.

In recent years significant development has taken place in the structural design of multistoried buildings, mainly based on the principles of composite construction. This will improve the speed of construction and reduce the overall construction cost. The main objective of steel framed composite floor construction is to provide a cost-effective alternative to the any other type of construction such as precast slab panel floor.

The building in case study is totally, a 10 storied modern multilevel car parking composite steel structure (Figure 1). It has rectangular $(50 \mathrm{~m} \times 64 \mathrm{~m})$ in plan with nominal height $31.5 \mathrm{~m}$ ( $3.15 \mathrm{~m}$ floor to floor height) 
and gross floor area $32000 \mathrm{~m} 2$ (3200 m2 at each floor), located at Infosys IT Park, Pune, India. The building is designed and constructed as post-tensioned composite steel beams having 10 and 16 meter spans (Figure 2). The 'Satyam' trapezoidal cold-formed steel deck profile is used for composite floor construction having $11500 \mathrm{~mm}$ length, $954 \mathrm{~mm}$ width and $1.00 \mathrm{~mm}$ thick.

Considering the same plan, total floor area, floor to floor height and loading condition, the existing steel framed composite floor structure is designed and constructed by other two ways;

- Precast concrete frame with precast concrete floor.

- Steel frame with precast concrete floor.

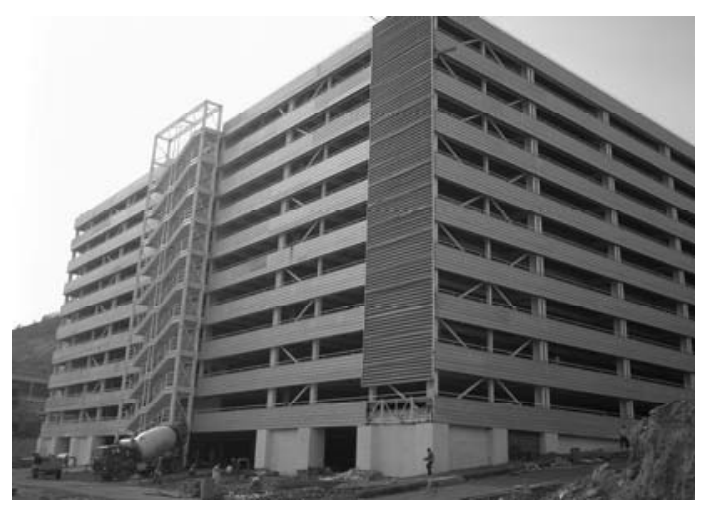

Figure 1: Multilevel Car Parking Steel Framed Composite Floor Building

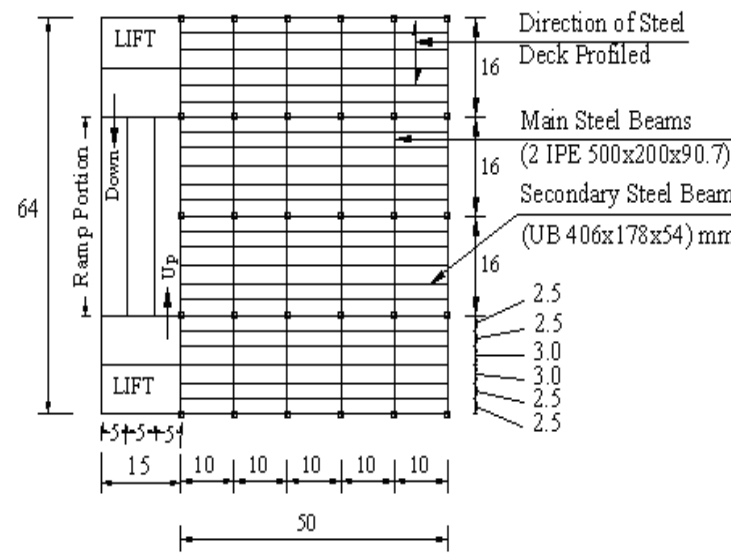

Figure 2: Typical Plan of Multilevel Car Parking Building

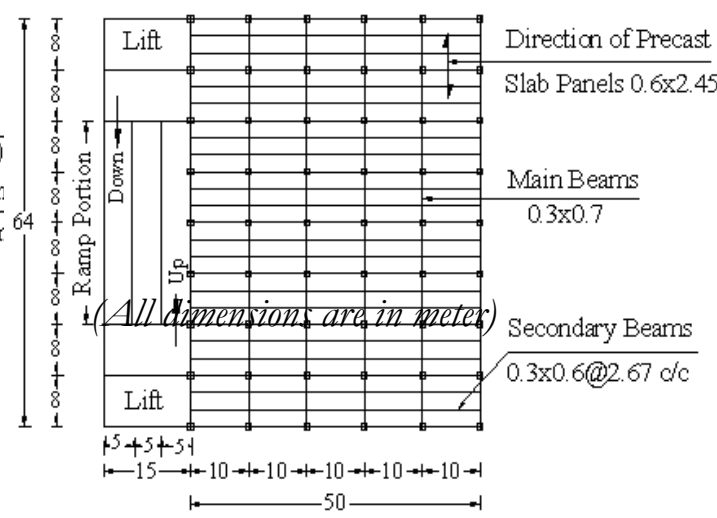

Figure 3: Typical Plan for Precast Frame with Precast Concrete Floor

In the first case, the structural members of the building viz. column, beam and slabs are designed and constructed as precast concrete members with Siporex slab panels [13]. For precast building, an additional column is introduced in between two columns of the whole span as shown in Figure 3. In second case, the structural members of the building viz. column and beams are designed and constructed as similar to case study and the construction of slab as a precast concrete floor with Siporex slab panels.

Two significant factors are considered for evaluating composite floor and pre-cast floor building, i.e. optimum time required for the construction and the total cost of buildings. The optimum time has been calculated by using Microsoft Project-2003 [9]. The construction of each structure is divided into various activities, which provide the relative time saving and the optimum time for construction. Considering all above parameters, the material and construction cost of buildings are calculated using market rates in the year 2007, for Pune (India). Structural element wise cost evaluation of all three structures is done as material and construction costs of buildings. However, study of comparison between composite floor and precast concrete floor is restricted to structural frame and slab only. 


\section{Salient Features of Multilevel Car Parking Building}

- It is a totally steel framed structure having capacity up to 2000 vehicles per 10 hours per day for first shift and minimum 1000 vehicles per 10 hours per day for second shift, vi\%: minimum 3000 vehicles per day.

- It is a unique structure in India, as it consist Post-tensioned composite beams. It helps to reduce sizes of the beam sections and also helps to keep larger clear span between two columns.

\section{Construction methodology of steel framed composite floor building}

Foundation of this building is normal box footings and RCC pedestals to hold steel columns. Anchor bolts of length $1200 \mathrm{~mm}$ is provided to hold huge steel columns in a position with special arrangement. Erection of column and beams of this building can be done in four stages. As shown in Figure 4, first lift includes the ground, first and second floor column and beams erection only. While second lift is in progress that time ground, first and second slab construction activities are in a progress. Likewise whole structure can be erected for all four lifts. Time scheduling gives clear idea about such simultaneous activities. After completion of column \& beams erection for first lift, at one time construction of composite floor is progresses for three floors. On third floor deck sheet placing, on second floor shear stud welding and on first floor reinforcement lying is in progress. This type of system allows many work faces open together and huge amount of time saving can be achieved. Figure 6 shows the section of composite floor slab with all details.

For pre-stressing of steel main beams, six cables on each side of the beam (includes six tendons in each cable) and for secondary beams, two cables on each side of the beam are placed with the help of fixtures. Post- tensioning operation is done in both directions $(50 \mathrm{~m}$ x $64 \mathrm{~m}$ ). In shorter direction cables are tensioned for five spans of $10 \mathrm{~m}$ lengths and in longer direction for four spans of $16 \mathrm{~m}$ lengths as shown in Figure 5. The construction activity of post-tensioning of composite steel beam is divided into three stages. In first stage, after 14 days of slab casting, the post-tensioning is with only $50 \%$ load. In second stage, after 21 days of slab casting, the post-tensioning is with $25 \%$ load. In third stage, after 28 days of slab casting, the post-tensioning is with $25 \%$ load. The full post-tensioning is done after 28 days of slab casting.

\section{Construction Methodology of Precast Frame with Precast Concrete Slab}

The structural analysis of precast building were carried by using STAAD Pro-2005 [12] and the precast members are designed as RCC structure [6, 7]. The construction schedule of PCC and RCC footing for precast concrete floor is same as that of steel frame with composite building. Only the numbers of PCC and RCC footings are increased which increased total duration and cost of project. The precast columns used are hollow precast section with sleeves at the top of column section for interlocking of column and beams. Before beams placing the two meter height hollow section of column is grouted with rich concrete of M30 grade by using the self compacted admixture viz. Viscous to reduce the porosity in concrete and above portion is grouted with screed concreting. Rectangular shaped partially precast beams with open stirrups and flanges of $100 \mathrm{~mm}$ width are provided for bearing between panel and beam sections (Figure 7). All the precast slab panels are $600 \mathrm{~mm}$ wide, $2450 \mathrm{~mm}$ long and $125 \mathrm{~mm}$ thick. Before placing of reinforcement and screed concrete, a layer of water repellent agent viz. silicon oil is applied on top surface of the panels. The dowel bars for beam, column and reinforcement steel for floor screed is laid on complete floor. The screed of $50 \mathrm{~mm}$ thickness is laid on the top of panels with a nominal reinforcement of $8 \Phi @ 250 \mathrm{~mm} \mathrm{c} / \mathrm{c}$ having concrete M25 grade.

\section{Construction Methodology of Steel Frame with Precast Concrete Floor}

All the structural members are designed and constructed according to Eurocode-4 [3], IS 13990 [6] and IS 13994 [7]. As compared with precast frame with precast concrete floor method, shear studs take the function of the dowel bar for beams. The composite action between steel beam and concrete slab through the use of shear connectors is responsible for a considerable increase in the load-bearing capacity and stiffness of the steel beams, which when utilized in design, can result in significant savings in steel weight and construction depth (Figure 8). The headed shear studs [1] as shown in Figure 8, are used with spacing 318 
$\mathrm{mm} \mathrm{c/c}$. The shear stud welding is done by self-taping machine, which reduce the time of activity; but this method is costly than normal welding method [11]. The screed of $50 \mathrm{~mm}$ thickness is placed with the nominal reinforcement of $8 \Phi @ 250$ mm c/c having M25 grade of concrete. The post-tensioning of steel beam is divided into three lifts, similar to the construction of steel framed composite floor building.

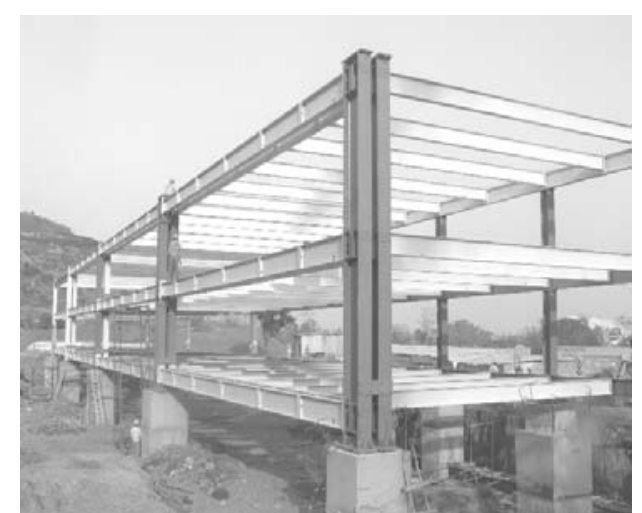

Figure 4: Erected Frame after 1st Lift

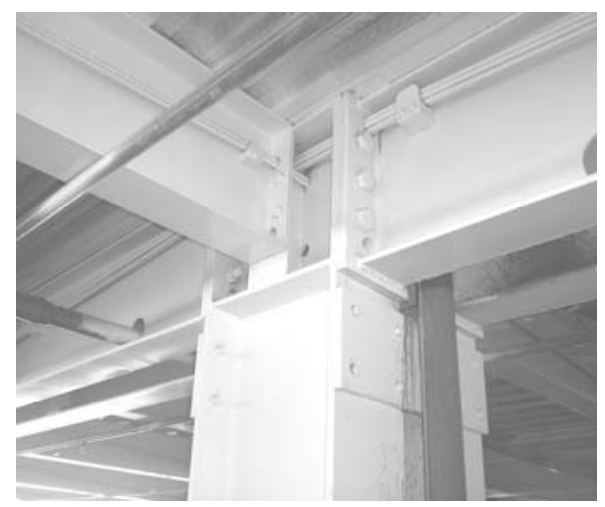

Figure 5: Post-tensioning cables at column junction

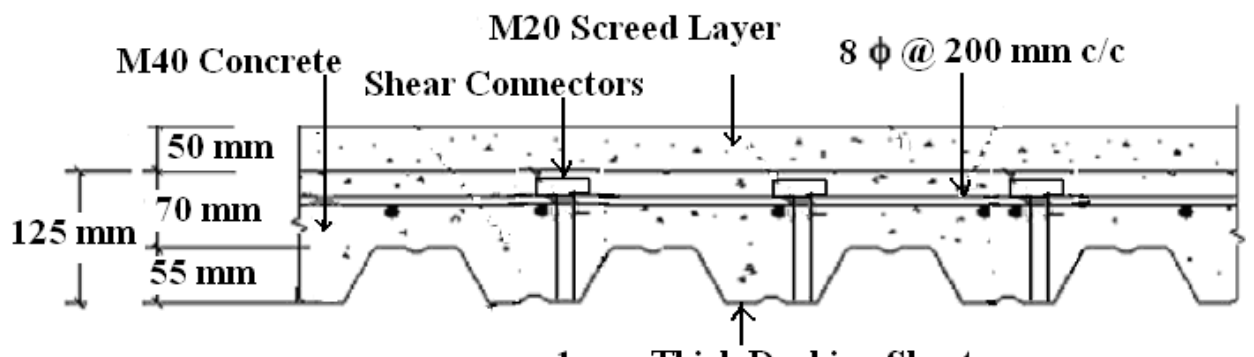

$1 \mathrm{~mm}$ Thick Decking Sheet

Figure 6: Section of Composite Slab
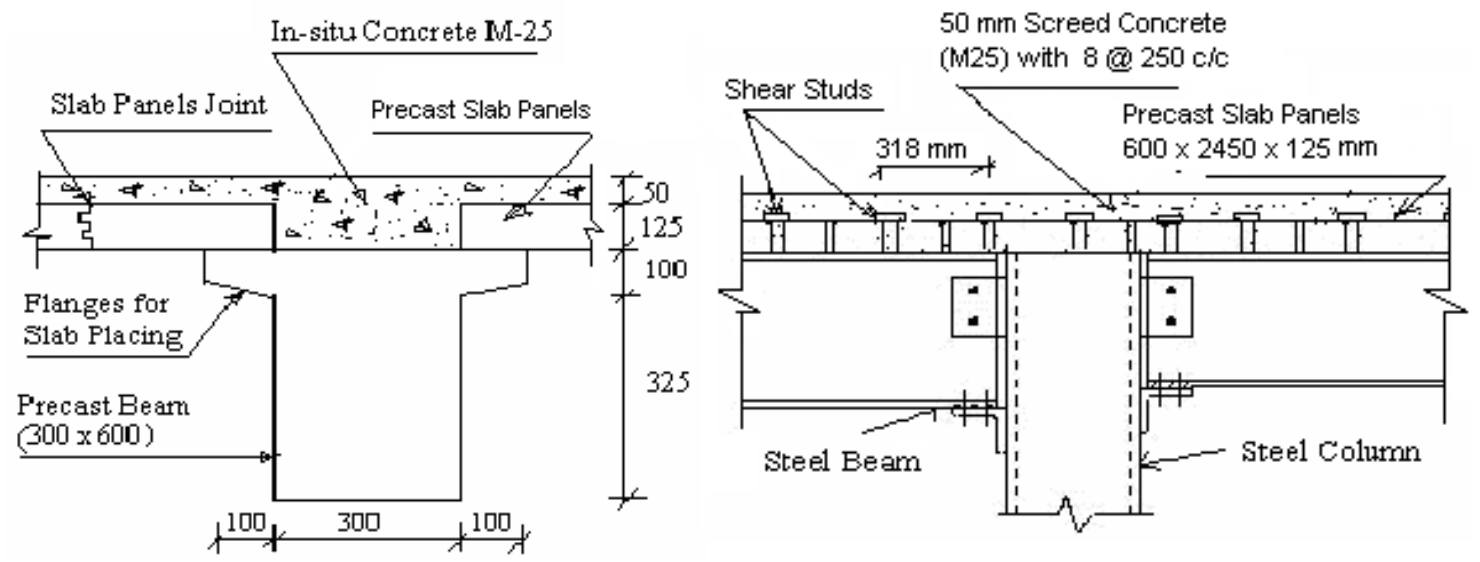

Figure 7: Section of Precast Concrete Figure 8: Section of Steel Frame Beam and Slab Panel with Precast Concrete Floor

\section{Time Scheduling:}

a) Steel Framed with Composite Floor:

Time scheduling is done using Microsoft Project 2003 [9]. In time scheduling some starting activities such as PCC (7 days), Footing (15 days), and Pedestal (7 days) goes individually but after completing column and beam erections for first lift (33 days), activities for composite floor construction goes simultaneously with second lift erection. Likewise whole structure can be erected with; so many works faces open together. 
For the construction of composite floor for all levels, requires 118 days as per time scheduling. It shows that ground and first floor slab activities and for all remaining floors activities are same as first floor. Considering time required for all floors, the building is completed in 180 working days (Figure 9). Total 210 days are required including holidays.

\section{b) Precast Framed with Precast Concrete Floor Building:}

Considering the lifting time for precast structural elements, the erection time for column and beams are increased with floor levels, viz. 10 days for first three floors to 12 days for last three floors. Placing of slab panels is started after 2 days of column grouting, it required 6 days for ground floor and 9 days for top floor with same workforce. In time scheduling, 12 days for PCC, 22 days for footings, and 150 days for first six floors construction viz. 25 days per floor and 104 days for next four floor construction viz. 26 days per floor are required. The erection of ground floor column started immediately after 14th day of footing construction, which saves 8 days to total duration. The total project completed in 280 working days (Figure10).

\begin{tabular}{|c|c|c|c|c|c|c|c|c|c|c|c|c|}
\hline ID & Task Name & Duration & \multicolumn{2}{|c|}{ February } & \multicolumn{2}{|c|}{ March } & \multicolumn{2}{|c|}{ April } & \multicolumn{2}{|c|}{ May } & \multicolumn{2}{|r|}{ June } \\
\hline 2 & $\mathrm{PCC}$ & 7 days & & & & & & & & & & \\
\hline 3 & Footing & 15 days & & & & & & & & & & \\
\hline 4 & Pedestal & 7 days & & & & & & & & & & \\
\hline 5 & 1 st Lift & 6 days & & & & & & & & & & \\
\hline 6 & 2 nd Lift & 6 days & & & & & & & & & & \\
\hline 7 & Column and Beam Erection & 110 days & & & & & & & & & & \\
\hline 8 & 1st Lift & 33 days & & & & & & & & & & \\
\hline 9 & 2nd Lift & 22 days & & & & & & & & & & \\
\hline 10 & 3rd Lift & 22 days & & & & & & & & & & 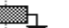 \\
\hline 11 & 4th Lift & 33 days & & & & & & & & & & \\
\hline 12 & Construction of Composite Floor & 118 days & & & & & & & & & & \\
\hline 13 & Slab Casting For 1st Lift & 33 days & & & & & & & & & & \\
\hline 14 & Ground Floor Slab & 21 days & & & & & & & & & & \\
\hline 15 & Placing of deck profile & 3 days & & & & & & & & & & \\
\hline 16 & Shear Studs Welding & 6 days & & & & & & & & & & \\
\hline 17 & Cover block Placing & 2 days & & & & & & & & & & \\
\hline 18 & Reinforcement Laying & 6 days & & & & & & & & & & \\
\hline 19 & Concreting & 2 days & & & & & & & & & & \\
\hline 20 & Post Tensioning of Bearns & 7 days & & & & & & & & & & \\
\hline 21 & 1st Floor Slab & 21 days & & & & & & & & & & \\
\hline 22 & Placing of deck profile & 3 days & & & & & & & & & & \\
\hline 23 & Shear Studs Welding & 6 days & & & & & & & & & & \\
\hline 24 & Cover block Placing & 2 days & & & & & & & & & & \\
\hline 25 & Reinforcement Laying & 6 days & & & & & & & & & & \\
\hline 26 & Concreting & 2 days & & & & & & & & & & \\
\hline 27 & Post Tensioning of Bearns & 7 days & & & & & & & & & & \\
\hline
\end{tabular}

Figure 9: Time Scheduling for Steel Framed Composite Floor Structure

\section{c) Steel Framed with Precast Concrete Floor Structure:}

For a partially precast slab construction, 10 workers are required for 10 days for placing precast slab panels, which include lifting, and fixing of slab joints in $14 \mathrm{hrs}$ working time. The concrete for floor is done by using concrete pump with 8 workers including pump operator in 2 days. Post-tensioning of steel beams are planned as same as steel frame with composite floor building. In time scheduling, 7 days for PCC, 15 days for footings, 7 days for pedestal, 110 days for column and beam erections are required and 33 days is delay to start the placing of Siporex slab panel's upto erection of first lift of column and beams, and 143 days for construction of precast concrete floor.

Each slab has slab cycle duration of 32 days but after interlinking of all activities for floor to floor and columns lift to lift, the total duration of three floors become 56 days. The total project completed in 205 working days (Figure11).

As shown in Figure 9, Figure 10 and Figure 11, the time estimation is carried by considering same starting date for all these three type of construction as 1st February 2007, which results into balancing of holidays, working and non-working days. The construction of multilevel car parking building with steel frame composite floor (180 days) saves 55\% time than precast frame with precast concrete floor (280 days) and $13 \%$ time than steel frame with precast concrete slab (205 days). 


\begin{tabular}{|c|c|c|c|c|c|c|}
\hline \multirow[t]{2}{*}{ ID } & \multirow[t]{2}{*}{ Task Name } & \multirow[t]{2}{*}{ Duration } & \multicolumn{4}{|c|}{ 2nd Quarter } \\
\hline & & & Feb & Mar & Apr & May \\
\hline 1 & Construction of Precast Frame with Precast Floor & 280 days & & & & \\
\hline 2 & PCC & 12 days & & & & \\
\hline 3 & Footing & 22 days & & & & \\
\hline 4 & Ground Floor Slab & 25 days & & & & \\
\hline 5 & Erection of Column \& Beam & 10 days & & & & \\
\hline 6 & Grouting of Column upto $2 \mathrm{~m}$ Height & 4 days & & + & & \\
\hline 7 & Placing of Precast Slab Panels & 6 days & & 4 & & \\
\hline 8 & Grouting of Slab Joint \& Silicon oil Apply & 4 days & & 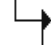 & & \\
\hline 9 & Reinforcement Laying \& Formwork Erection & 6 days & & & & \\
\hline 10 & Concreting & 2 days & & & & \\
\hline 11 & 1St Floor Slab & 25 days & & & & \\
\hline 12 & Erection of Column \& Beam & 10 days & & & & \\
\hline 13 & Grouting of Column upto $2 \mathrm{~m}$ Height & 4 days & & & 要 & \\
\hline 14 & Placing of Precast Slab Panels & 6 days & & & +2 & \\
\hline 15 & Grouting of Slab Joint $\&$ Silicon oil Apply & 4 days & & & $\rightarrow$ & \\
\hline 16 & Reinforcement Laying \& Forrnwork erection & 6 days & & & & \\
\hline 17 & Concreting & 2 days & & & & \\
\hline
\end{tabular}

Figure 10: Time scheduling for Precast Frame with Precast Concrete Floor

\begin{tabular}{|c|c|c|c|c|c|c|c|}
\hline \multirow[t]{2}{*}{ ID } & \multirow[t]{2}{*}{ Task Name } & \multirow[t]{2}{*}{ Duration } & \multicolumn{5}{|c|}{ 2nd Quarter } \\
\hline & & & Feb & Mar & Apr & May & Jun \\
\hline 1 & Construction of Steel Frame with Precast Floor & 205 days & & & & & \\
\hline 2 & $\mathrm{PCC}$ & 7 days & & & & & \\
\hline 3 & Footing & 15 days & & & & & \\
\hline 4 & pedestal & 7 days & & & & & \\
\hline 5 & 1st Lift & 6 days & & & & & \\
\hline 6 & 2nd Lift & 6 days & & & & & \\
\hline 7 & Column and Beam Erection & 110 days & & & & & \\
\hline 8 & 1st lift & 33 days & & & & & \\
\hline 9 & 2nd lift & 22 days & & & & & \\
\hline 10 & 3rd lift & 22 days & & & & & \\
\hline 11 & 4th lift & 33 days & & & & & \\
\hline 12 & Construction of Precast Floor & 143 days & & & & & \\
\hline 13 & Slab Casting For 1st Lift & 56 days & & & & & \\
\hline 14 & Ground Floor Slab & 32 days & & & & & \\
\hline 15 & Placing of precast slab panels & 10 days & & & & & \\
\hline 16 & Shear Stud Welding & 4 days & & & & & \\
\hline 17 & Grouting Slab Joint & 4 days & & & & & \\
\hline 18 & Reinforcement Laying \& Formwork । & 8 days & & & & & \\
\hline 19 & Concreting & 2 days & & & & & \\
\hline 20 & Posttensioning & 7 days & & & & & \\
\hline 21 & 1st Floor Slab & 33 days & & & & & \\
\hline 22 & Placing of precast slab panels & 10 days & & & & & \\
\hline 23 & Shear Stud Welding & 5 days & & & & & \\
\hline 24 & Grouting Slab Joint & 4 days & & & & & \\
\hline 25 & Reinforcement Laying \& Formwork & 8 days & & & & & \\
\hline 26 & Concreting & 2 days & & & & & \\
\hline 27 & posttensioning & 7 days & & & & & \\
\hline
\end{tabular}

Figure 11: Time scheduling for Steel Frame with Precast Concrete Floor

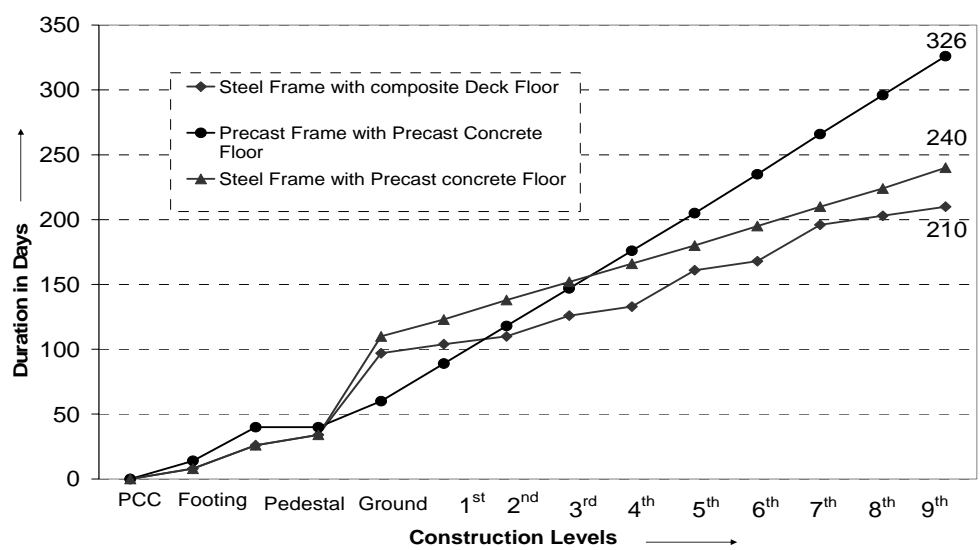

Figure 12: Floor wise Comparison of structures

Figure 12, shows that, after considering one holiday per week, the construction of steel frame composite floor (210 days) saves 55.3\% time than that of precast frame with precast concrete floor (326 days) and 
$14.3 \%$ time than that of steel frame with precast concrete slab (240 days).

\section{Cost Estimation}

a) Direct Cost of Projects:

The total cost of project is divided into four major construction activities such as, foundation, column, beam and slabs construction. Figure 13 and Figure 14 indicate distribution of material and construction cost for these activities, respectively, for each type of building. Same aspect is presented as \% of total cost of project in Table 1.

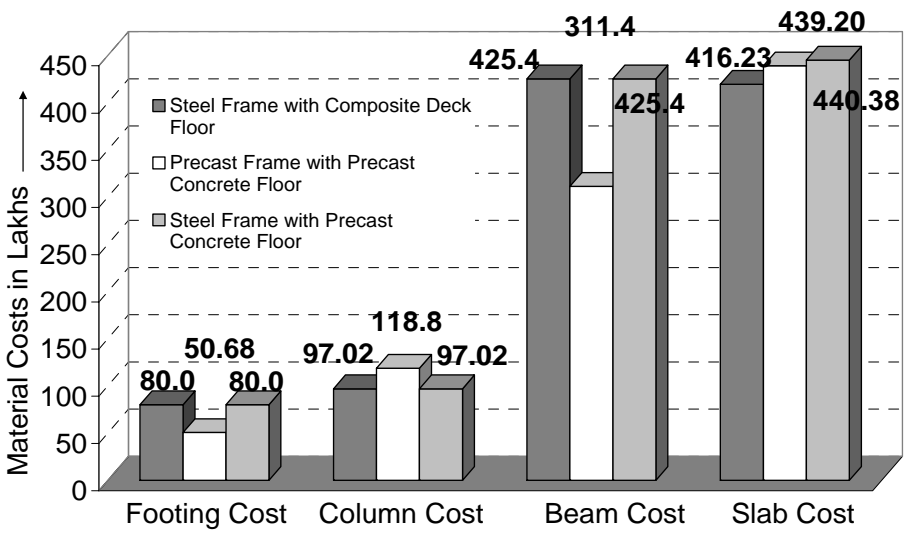

Figure 13: Material Cost of Buildings (As per year 2007)

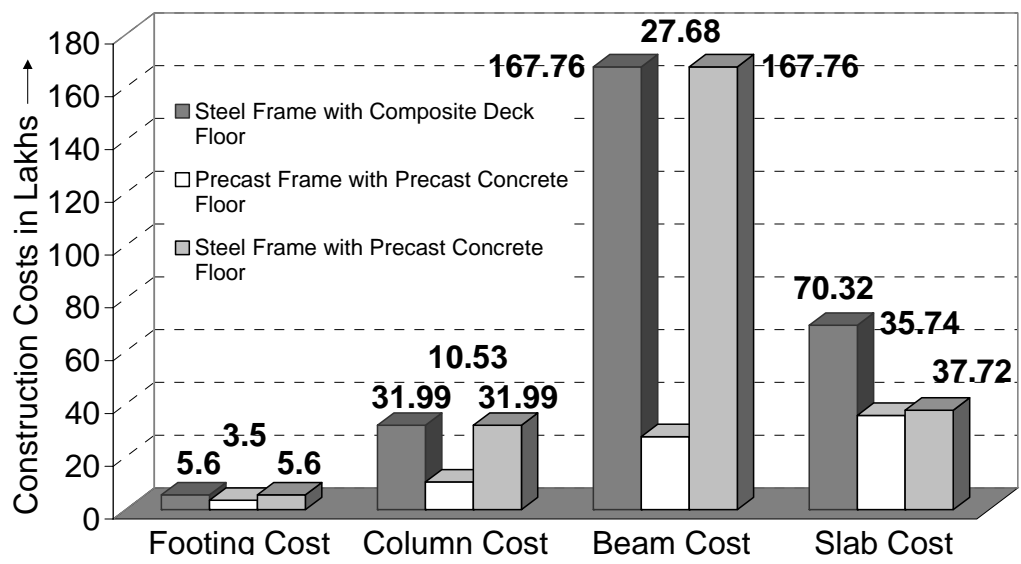

Figure 14: Construction Cost of Buildings (As per year 2007)

Table 1: Percentage of total cost of projects

\begin{tabular}{|l|c|c|c|}
\hline \multirow{2}{*}{$\begin{array}{c}\text { Structural } \\
\text { Elements }\end{array}$} & \multicolumn{3}{|c|}{ Material and Construction cost as \% of total cost of projects } \\
\cline { 2 - 4 } & $\begin{array}{c}\text { Steel frame with } \\
\text { precast Concrete floor }\end{array}$ & $\begin{array}{c}\text { Precast concrete frame } \\
\text { with precast concrete } \\
\text { floor }\end{array}$ & $\begin{array}{c}\text { Steel frame with } \\
\text { precast Concrete floor }\end{array}$ \\
\hline Foundation & 7 & 6 & 7 \\
\hline Column & 10 & 12 & 10 \\
\hline Beam & $45^{*}$ & 34 & $46^{*}$ \\
\hline Slab & 38 & 48 & 37 \\
\hline
\end{tabular}

* Steel beams with post tensioning.

It is observed that for the steel frame with composite floor building and steel frame with precast concrete floor structure, the maximum material cost is associated with beams and slabs material while maximum 
construction cost with erection of post-tensioned beam. For precast frame with precast concrete floor structure, the maximum material cost is associated with slab and beams material and maximum construction cost with erection of slab panels.

Table 2 shows, the percentage increase in material and construction cost of structural elements for other two buildings as compared to steel frame with composite deck floor. The negative values indicate that extra cost is required for it. For precast structure, the total percentage of cost savings are associated with, beam cost $(42.83 \%)$, footing cost $(36.27 \%)$, and slab cost $(2.38 \%)$ and the cost of column is slightly extra by only $0.25 \%$ compared to steel frame with composite deck floor. Similarly the percentage of cost savings are associated with beam cost (42.83\%), footing cost (36.27\%), and a little saving in slab cost as $1.64 \%$ as compared to steel framed with precast concrete floor structure.

As compared with steel framed with composite deck floor, the total cost saved through precast frame with precast concrete floor construction is about $23.10 \%$, and the cost saved through steel framed with precast concrete floor construction is only $0.52 \%$. The cost saved for precast frame with precast concrete floor is about $22.70 \%$ as compared to steel frame with precast concrete floor. The costs for foundations and costs of columns for all these type of building is least amount as evaluated with cost of beam and slabs construction. The cost of large span post-tensioning composite steel beam affect on the total project cost, project cost increased by $11 \%$ of total cost of projects. The reduction in total cost of steel building is attributed to cost of steel being higher than concrete.

Table 2: Percentage Increase in Cost Compared to Steel Frame with Composite Deck Floor

\begin{tabular}{|c|c|c|c|c|c|c|c|}
\hline \multirow{2}{*}{$\begin{array}{c}\text { Sr. } \\
\text { No. }\end{array}$} & \multirow{2}{*}{$\begin{array}{c}\text { Structural } \\
\text { Elements }\end{array}$} & \multicolumn{3}{|c|}{$\begin{array}{c}\text { Precast Concrete Frame with } \\
\text { Precast Concrete Floor (\%) }\end{array}$} & \multicolumn{3}{|c|}{$\begin{array}{c}\text { Steel Frame with Precast } \\
\text { Concrete Floor (\%) }\end{array}$} \\
\cline { 3 - 8 } & $\begin{array}{c}\text { Material } \\
\text { Cost }\end{array}$ & $\begin{array}{c}\text { Construction } \\
\text { Cost }\end{array}$ & $\begin{array}{c}\text { Total } \\
\text { Cost }\end{array}$ & $\begin{array}{c}\text { Material } \\
\text { Cost }\end{array}$ & $\begin{array}{c}\text { Construction } \\
\text { Cost }\end{array}$ & $\begin{array}{c}\text { Total } \\
\text { Cost }\end{array}$ \\
\hline 1 & Foundation & 36.68 & 36.88 & 36.27 & 0 & 0 & 0 \\
\hline 2 & Column & -22.44 & 67.08 & -0.25 & 0 & 0 & 0 \\
\hline 3 & $\begin{array}{c}\text { Beam + PT } \\
\text { Beam }\end{array}$ & 26.80 & 83.50 & 42.83 & 0 & 0 & 0 \\
\hline 4 & Slab & -2.80 & 48.80 & 2.38 & -6.05 & 45.99 & 1.34 \\
\hline
\end{tabular}

\section{b) Net Cost of Projects:}

The net cost of project is including the extra cost incurred in interest on barrowed money and car parking rent on saved days of construction, material cost and construction cost of projects, are calculated and compared by considering time related saving, the interest cost on barrowing money and the cost required for car parking rent for saved days of construction. The extra costs of projects are calculated based on interest rate and parking charges in Table 3.

Interest Rate: By taking the survey of various banks and some reputed construction companies, the data for interest rate on the barrowing money is collected and the average interest rate for commercial constructions is considered as $11 \%$.

Parking Charges:

- Parking charges at multilevel car parking building decided by Infosys: Rs. 900/- per month per vehicle.

- Parking capacity: 3000 vehicles per day (as mention in section-3)

- Extra cost required for car parking rent for saved days,

$$
=\text { Days saved in construction * No. of vehicles * parking charges } / 30
$$

The extra cost for all three projects are calculated and compared with the steel frame with composite deck floor. The cost saved for precast frame with precast concrete floor structure is about $12.99 \%$ and for steel frame with precast floor structure $-2.32 \%$. The negative value in table indicates extra cost is required than composite deck floor construction. The cost saved for precast frame with precast concrete floor in comparison of steel frame with precast concrete floor structure is about $14.96 \%$ 
Table 3: Time and Cost of Projects (For the year 2007):

\begin{tabular}{|l|c|c|c|}
\hline \multicolumn{1}{|c|}{ Costs } & $\begin{array}{c}\text { Steel Frame } \\
\text { with Composite } \\
\text { Deck Floor }\end{array}$ & $\begin{array}{c}\text { Precast Concrete } \\
\text { Frame with Precast } \\
\text { Concrete Floor }\end{array}$ & $\begin{array}{c}\text { Steel Frame with } \\
\text { Precast Concrete } \\
\text { Floor }\end{array}$ \\
\hline $\begin{array}{l}\text { Total project duration } \\
\text { (Days) }\end{array}$ & 210 & 326 & 240 \\
\hline Direct cost in Lakhs & 1297.37 & 997.575 & 1290.679 \\
\hline $\begin{array}{l}11 \% \text { interest on } \\
\text { Direct cost in Lakhs }\end{array}$ & 82.120 & 98.015 & 93.353 \\
\hline $\begin{array}{l}\text { Extra cost required for } \\
\text { car parking rent for } \\
\text { saved days }\end{array}$ & 0 & 104.400 & 27.000 \\
\hline Net cost in Lakhs & 1379.484 & 1199.983 & 1411.032 \\
\hline Net cost in Rs /m ${ }^{2}$ & 4310 & 3750 & 4410 \\
\hline $\begin{array}{l}\% \text { cost savings as compared to steel frame } \\
\text { with composite deck floor }\end{array}$ & 12.99 & -2.32 \\
\hline $\begin{array}{l}\% \text { cost savings as compared to precast frame with precast } \\
\text { concrete floor }\end{array}$ & & -14.96 \\
\hline
\end{tabular}

\section{Conclusions}

Following are the conclusions drawn out from study:

- The study shows that the time savings of $55.3 \%$ is achieved due to use of steel framed composite floor construction rather than precast framed with precast concrete floor and $14.3 \%$ time than that of steel framed with precast concrete slab. The construction of steel framed composite floor building saves time, which leads to an overall savings in net cost.

- The direct cost required for steel framed with composite floor is $23.10 \%$, higher than precast frame with precast concrete floor and only $0.52 \%$ higher than steel framed with precast concrete floor. Considering time related savings, the net cost required for steel framed with composite floor is $12.99 \%$, more than precast frame with precast concrete floor and $2.32 \%$ less than steel frame with precast floor.

- The steel framed with precast concrete floor saves $35.83 \%$ construction time than precast frame with precast concrete floor, which required extra $22.70 \%$ of direct cost and $14.96 \%$ of net cost.

- However, study is restricted to structural frame only. If other items are also considered in the study like excavation work, finishing items, services, cladding etc. and also during construction preliminaries such as labour accommodations, their travelling and food expenses and many other factors related to time, then definitely, steel framed composite floor building option will become cost effective.

- Post-tensioned composite beam is very recent technique and multilevel car parking building might be only structure in India, which has such technique. So cost of material and labour to adopt such new technique is high.

- In present Indian construction sector, there are very less cold-formed trapezoidal profiled steel deck manufacturers. Obviously due to less competition, material rates are much higher. But from present status and already announced investment, future of Indian steel production industry is very bright for cold-formed steel deck sections. So in near future definitely, steel prices will be reduced and steel framed composite floor construction will become competitive in Indian construction sector. 


\section{References}

[1] Dennis, Lam., Elliott, K.S., and Nethercot, D.A. (2000). "Parametric study on composite steel beams with precast concrete hollow core floor slabs.” J. Construction Steel Research, 54, 283-304.

[2] Elliott, K. S., Davies, G., and Bensalem, K. (1993). "Precast floor slab diaphragms without structural screed." Proc., Concrete-2000, Economic and durable construction through excellence, University of Dundee, Scotland, UK.

[3] Eurocode-4 (2003). "Design of composite steel and concrete structures-Part 1.1. General rules and rules for buildings." EN 1994-1-1:2003.

[4] Hicks, S. J., Lawson, R. M., Rackham, J. W., and Fordham, P. (2004). "Comparative Structure Cost of Modern Commercial Buildings.” IInd Edition, SCI P137, Steel Construction Institute Publication.UK.

[5] Hedaoo, N. A., Athare, D. S. (2006). "Composite floor system-A cost effective study." J. Concrete India, India Chapter of ACI, 21(4), 3-8.

[6] IS: 13990 (1994). "Indian standard code of precast reinforced concrete planks and joists for flooring and flooring-specification." Bureau of Indian Standard, New Delhi.

[7] IS: 13994 (1994). "Indian standard code of Design and construction of floor and roof with precast reinforced concrete planks and joists." Bureau of Indian Standard, New Delhi.

[8] Langdon Davis (2004). "Multi-storey residential buildings, the cost benefits of steel." Corus Construction Ltd., UK.

[9] Microsoft Project-2003. (2003). "Microsoft Corporation." One Microsoft Way, Redmond, WA98052-7329, USA.

[10] Murunde, Celikag. (2004). "Economic aspects of using steel framed buildings with composite floors: case studies from United Arab Emirates.” J. Const. \& Building Materials, 18, 383-390.

[11] Report of committee on composite construction. (2002). "Construction considerations for composite steel-and-concrete floor systems.” J. Struct. Eng., ASCE, 128(9), 1099-1110.

[12] STADD Pro-2005. (2005). "Research Engineers Ltd.," U.S.A.

[13] Siporex India Pvt. Ltd., Pune, India. "Manufacturers of Concrete Precast Slab Panels." 